\title{
UPAYA PEMANGGILAN PAKSA OLEH BADAN PENYELESAIAN SENGKETA KONSUMEN (BPSK) TERHADAP PELAKU USAHA YANG TIDAK HADIR DALAM PENYELESAIAN SENGKETA KONSUMEN
}

\author{
Rai Mantili \\ Dosen Hukum Acara Perdata Fakultas Hukum Universitas Padjajaran, Bandung \\ rai@unpad.ac.id
}

\begin{abstract}
One of the authorities of the Consumer Dispute Settlement Agency (BPSK) is to receive both written and unwritten complaints from consumers regarding the occurrence of violations of consumer protection. Article 52 Sub-Article g of the Consumer Protection Law (UUPK) authorizes BPSK to summon business actors who allegedly violate consumer protection. However, in practice in the field, BPSK is not authorized to force involuntary calling of business actors so that many business actors refuse to be present at consumer dispute resolution in BPSK.

This research is Normative and Analytical Descriptive Research. In this case, it is a Normative Legal Research in the form of research to find the Law of Concreto, the research to find the law for a case in concreto is an attempt to find out whether the appropriate law to apply in cocreto in order to solve a particular case and see the rule of law is found. This research will illustrate various legal issues and other symptoms related to cases concerning consumer protection and BPSK

Implementation of consumer protection law enforcement in practice is not yet fully feasible. It can be seen apart from awareness of the ability and independence of consumers to protect themselves against the rights and kewajibanya, also can be seen from law enforcement officers who have not performed optimally. efforts that can be made by BPSK after forced calling of business actors who refuse to attend the consumer dispute resolution can make a verdict verdict if the business actor is not present 3 times on the summons of the session by BPSK as stipulated in Article 52 UUPK and Kemendag. 35/2001.
\end{abstract}

Keywords: BPSK, Forced Calling, Consumer Dispute Resolution

\section{A. Latar Belakang}

Badan Penyelesaian Sengketa Konsumen (BPSK) adalah lembaga non struktural yang berkedudukan di seluruh Kabupaten dan Kota yang mempunyai fungsi "menyelesaikan sengketa konsumen di luar pengadilan". Keanggotaan BPSK terdiri dari unsur Pemerintah, konsumen dan unsur pelaku usaha. BPSK bertugas untuk mempermudah, mempercepat dan memberikan suatu jaminan kepastian hukum bagi konsumen untuk menuntut hak-hak perdatanya kepada pelaku usaha.
Dalam penanganan dan penyelesaian sengketa konsumen, BPSK berwenang melakukan penelitian dan pemeriksaan terhadap bukti surat, dokumen, bukti barang, hasil uji laboratorium, dan bukti-bukti lain, baik yang diajukan oleh konsumen maupun oleh pelaku usaha. Prinsip dasar penyelesian, di BPSK, sebagaimana diutarakan oleh Direktorat Jenderal Perlindungan Konsumen dan Tertib Niaga, antara lain

1.Penyelesaian sengketa konsumen melalui BPSK berdasarkan pilihan sukarela para pihak yang 
bersengketa. Cara penyelesaian sengketa yang berlaku di BPSK adalah konsiliasi atau mediasi atau arbitrase.

2. Bukan berjenjang. Jika penyelesian sengketa melalui konsiliasi tidak terdapat penyelesaian, maka akan diajukan penyelesaian dengan cara mediasi atau arbitrase.

3. Bila para pihak sepakat memilih penyelesaian secara konsiliasi atau mediasi, maka Majelis BPSK berfungsi sebagai fasilitator yang wajib memberikan masukan, saran, dan menerangkan isi Undang-Undang Perlindungan Konsumen sebagai dasar penyelesaian sengketa.

4. Bila pihak bersengketa sepakat memilih penyelesaian secara arbitrase, maka penyelesaian sepenuhnya diserahkan kepada Majelis BPSK baik bentuk dan besarnya ganti rugi.

5. Pada prinsipnya penyelesaian sengketa konsumen melalui BPSK tanpa lawyer (pengacara), yang diutamakan dalam proses penyelesaian sengketa adalah musyawarah kekeluargaan.

6. Penyelesaian sengketa di BPSK tidak dipungut biaya dari pihak yang bersengketa dan waktu penyelesaiannya selambat-lambatnya 21 hari kerja sudah diterbitkan putusan BPSK.

Pasal 52 huruf g UUPK memang memberikan kewenangan pada BPSK untuk memanggil pelaku usaha yang diduga telah melakukan pelanggaran terhadap perlindungan konsumen. Akan tetapi, BPSK tidak diberikan kewenangan untuk melakukan pemanggilan paksa terhadap pelaku usaha tersebut. Meski demikian, BPSK bisa meminta bantuan penyidik untuk menghadirkan pelaku usaha yang tidak bersedia memenuhi panggilan badan penyelesaian sengketa konsumen sebagaimana yang disebutkan dalam Pasal 52 huruf i UUPK. BPSK tidak memiliki kewenangan untuk melakukan pemanggilan paksa, tetapi BPSK bisa meminta bantuan pada penyidik untuk menghadirkan pelaku usaha. Penyidik di sini mengacu pada Pejabat Polisi Negara Republik Indonesia dan Pejabat Pegawai Negeri Sipil tertentu di lingkungan instansi pemerintah yang lingkup tugas dan tanggung jawabnya di bidang perlindungan konsumen.

Dalam hal pelaku usaha tetap tidak memenuhi panggilan BPSK, maka BPSK dapat mengadili sengketa konsumen tanpa kehadiran pelaku usaha. Hal ini mengacu pada Pasal 36 Keputusan Menteri Perindustrian dan Perdagagangan No 350 Tahun 2001 (Kepemenperindag No. 350/2001), yaitu dalam hal pelaku usaha tidak hadir pada hari persidangan I (pertama) ,majelis hakim BPSK akan memberikan kesempatan terakhir kepada pelaku usaha untuk hadir pada persidangan II (kedua) dengan membawa alat bukti yang diperlukan. Jika pada persidangan II (kedua) pelaku usaha tidak hadir, maka gugatan konsumen dikabulkan oleh Majelis tanpa kehadiran pelaku usaha. Jadi, dalam hal pelaku usaha tidak menghadiri persidangan, maka BPSK dapat mengabulkan gugatan konsumen. Adapun putusan BPSK sendiri adalah putusan yang final dan telah mempunyai kekuatan hukum yang tetap. Final artinya dalam badan penyelesaian sengketa konsumen tidak ada upaya banding dan kasasi. Putusan BPSK kemudian dapat dimintakan penetapan eksekusi oleh BPSK kepada Pengadilan Negeri di tempat konsumen yang dirugikan.

BPSK berdiri melalui UUPK tahun 2000, namun selama itu pula masih banyak konsumen yang dirugikan karena para pelaku usaha lebih memilih sidang di pengadilan karena penyelesaian sengketa konsumen di BPSK masih belum optimal dan belum merata. Pada umumnya BPSK mengalami kendala dana operasional dan SDM sehingga kinerjanya kurang optimal. Kendala khusus yang membuat kurang optimalnya BPSK adalah pelaku usaha yang sering menolak surat panggilan. Lalu pemanggilan dengan bantuan polisi tidak dapat dilakukan BPSK karena tak tercantum dalam berbagai aturan atau keputusan Kementrian Perdagangan. Selain itu, para pelaku usaha yang setuju menyelesaikan sengketa konsumen di BPSK kerap tidak menyepakati cara penyelesaian yang ditawarkan BPSK, yakni konsolidasi, mediasi, dan arbitrase. Lalu para pelaku usaha juga tidak bersedia melaksanakan putusan BPSK. Hal ini terlihat dalam prakteknya, pihak kepolisian tidak 
dapat memenuhi permintaan BPSK agar pihak kepolisisan dapat melakukan penyidikan terhadap pelaku usaha yang tidak bersedia melaksanakan putusan BPSK

Menurut pakar hukum perdata Susanti Adi Nugroho, ada lima masalah terkait UU yang menjadi tempat BPSK berpijak. Baik UndangUndang No. 8 tahun 1999 tentang Perlindungan Konsumen (UUPK) maupun Kepemenperindag No. 350/2001 tidak cukup memberikan kejelasan yang dibutuhkan untuk implementasi di lapangan. Lima masalah itu adalah ketentuan peraturan dan perundangan yang multi tafsir, tidak ada pasal yang konsisten, pertentangan antara pasal yang satu dengan yang lainnya, konflik peraturan perundangan arbitrase, dan tidak adanya kejelasan peran penyidik. Secara umum, banyak kelemahan dalam UU yang mengatur tugas pokok dan fungsi BPSK Dalam praktik, tidak ada petunjuk teknis bagi penyidik untuk melaksanakan upaya paksa. Pelaku usaha yang tidak mau hadir maka putusannya dapat dilakukan tanpa dihadiri pihak pelaku usaha, berlaku sebaliknya untuk konsumen Tata cara persidangan menurut Pasal 26 Kepemenperindag No. 350/2001, ketua BPSK memanggil pelaku usaha selambat-lambatnya dalam waktu 3 (tiga) hari sejak permohonan penyelesaian sengketa diterima secara benar dan lengkap sesuai dalam Pasal 16 Kepemenperindag No. 350/2001. Dalam surat panggilan tersebut dicantumkan secara jelas mengenai hari, tanggal, jam dan tempat persidangan serta kewajiban pelaku usaha untuk memberikan surat jawaban terhadap penyelesaian sengketa konsumen dan disampaikan pada hari sidang pertama.

Ketentuan mengenai Pasal 26 Kepemenperindag No. 350/2001 terkesan menimbulkan anggapan apabila konsumen telah mengupayakan permohonan sengketa konsumen ke BPSK maka pelaku usaha terikat mengikuti kemauan atau pilihan konsumen.

Berdasarkan penelitian lapangan yang dilakukan di BPSK kota Bandung, sebelum persidangan ada suatu tahap yang dinamakan prasidang. Prasidang ini tidak diatur dalam UUPK maupun Kepemenperindag No. 350/2001. Pemanggilan awal yang dilakukan kepada pelaku usaha ialah pemanggilan kepada para pihak yang bersengketa untuk menghadiri prasidang. Prasidang ini merupakan suatu tahap untuk mempertemukan para pihak bersengketa untuk menentukan cara penyelesaian sengketa yang akan digunakan dan penunjukan majelis. Namun ada kendala dalam pemanggilan pelaku usaha tersebut, karena pelaku usaha belum tentu sanggup untuk menghadiri pemanggilan tersebut, bahkan bisa saja tidak bersedia untuk menyelesaiakan sengketanya melalui BPSK, dan BPSK pun tidak memiliki kewenangan untuk melakukan pemanggilan secara paksa. Jika pelaku usaha tidak bersedia hadir, maka BPSK tidak bisa berbuat apa-apa, dan sengketa konsumen tidak bisa diproses lebih lanjut. Berdasarkan latar belakang yang telah diuraikan di atas, maka penulis membatasi permasalahanpermasalahan yang akan diteliti sebagai berikut :

1.Bagaimana implementasi penegakan hukum perlindungan konsumen BPSK dalam pelaksanaan penyelesaian sengketa konsumen dalam praktik?

2.Bagaimana upaya BPSK setelah melakukan pemanggilan paksa terhadap pelaku usaha yang menolak hadir pada penyelesaian sengketa konsumen?

\section{B. Pembahasan \\ 1. Implementasi Penegakan Hukum BPSK Dalam Pelaksanaan Penyelesaian Sengketa Konsumen Dalam Praktik}

Pembangunan nasional di Indonesia bertujuan untuk mewujudkan masyarakat yang adil dan makmur yang merata baik secara mateiil maupun spiritual dalam era ekonomi yang berdasarkan Pancasila dan Undang-Undang Dasar 1945. Pembangunan ekonomi nasional di era globalisasi harus dapat mendukung pertumbuhan dunia usaha, sehingga mampu menghasilkan keanekaragaman barang dan atau jasa yang berkualitas baik dan dapat meningkatkan kesejahteraan masyarakat banyak serta mampu memberikan kepastian dari produk yang dihasilkan tanpa mengakibatkan kerugian bagi konsumen.

Tak dapat dipungkiri bahwa semua orang dalam masyarakat tanpa melihat pada kedudukan dan status sosialnya, baik itu konsumen maupun 
pelaku usaha adalah konsumen dari setiap barang dan atau jasa yang tersedia di masyarakat. Sebagai konsumen, kita berkepentingan akan perlindungan hukum sehubungan dengan kualitas dan kuantitas barang dan atau jasa. Yang dimaksud konsumen adalah setiap orang yang mendapatkan dan menggunakan barang dan atau jasa untuk memenuhi kebutuhan hidup pribadinya, keluarga maupun rumah tangga dan tidak untuk diperdagangangkan kembali Pengertian konsumen ini haruslah dibedakan dengan konsumen antara yaitu setiap orang yang mendapatkan barang dan atau jasa untuk digunakan dengan tujuan membuat barang dan atau jasa untuk diperdagangkan (tujuan komersial).

Masalah perlindungan konsumen yang secara tegas ditangani secara khusus baru dikenal dan tumbuh di Indonesia sejak 10 tahun yang lalu sehingga memang belum mengakar pada segenap lapisan masyarakat. Keengganan konsumen sebelum diundangkannya UUPK lebih didasarkan pada:

1. Tidak jelasnya norma-norma perlindungan konsumen

2. Praktik peradilan yang tidak berdasarkan asas sederhana, cepat, dengan biaya ringan.

3. sikap menghindari konflik meskipun hak haknya sebagai konsumen dilanggar oleh pelaku usaha.

Keberadaan UUPK bertujuan untuk memberikan kepastian hukum bagi konsumen karena usaha untuk melindungi kepentingan konsumen harus dilakukan pertama tama melalui penyusunan seperangkat aturan hukum yang diikuti dengan penegakan hukum (law enforcement), menumbuh kembangkan sikap pelaku usaha yang bertangggung jawab, dll. Maka dapat dikatakan bahwa prinsip perlindungan hukum bagi konsumen di Indonesia adalah prinsip pengakuan dan kesederajatan yang bersumber dari Pancasila.

Setiap pekerjaan mempunyai tujuan. Terkait dengan hal ini, konsumen telah mengalami pertumbuhan seiring dengan semakin kompleksnya permasalahan yang dialami konsumen, salah satunya adalah masalah yang berhubungan dengan kerugian yang diderita konsumen akibat menggunakan barang cacat dan berbahaya.
Sesungguhnya, antara konsumen dan pelaku usaha memiliki hubungan saling membutuhkan dan sederajat hak-haknya sehingga pada akhirnya menimbulkan kewajiban serta tanggung jawab pelaku usaha terhadap barang - barang yang dibeli oleh konsumen dari pelaku usaha.

Hubungan hukum dan/atau masalah antara konsumen dengan penyedia barang atau penyelenggara jasa, umumnya terjadi melalui suatu perikatan, baik karena perjanjian atau karena undang-undang. Perikatan dapat terjadi tanpa adanya perjanjian, seperti terjadinya perbuatan kealpaan yang melanggar dan melawan hukum. Apabila seseorang dirugikan karena perbuatan seseorang lain, sedang diantara mereka itu tidak terdapat sesuatu perjanjian (hubungan hukum perjanjian), maka berdasarkan undang-undang dapat juga timbul atau terjadi hubungan hukum antara orang tersebut dan orang yang menimbulkan kerugian itu. Tanggung jawab untuk mengganti rugi tidak saja karena dilakukannya perbuatan melanggar hukum, tetapi juga karena kelalaian atau kurang hati-hati. Bahkan tanggung jawab itu tidak hanya karena kelalaian atau kurang hati-hati. Bahkan tanggung jawab itu tidak hanya karena perbuatan atau tidak berbuat pelaku sendiri, tetapi juga karena perbuatan atau tidak berbuat dari orang-orang yang menjadi atau termasuk tanggung jawabnya.

Perbuatan melawan hukum itu tidak saja merupakan perbuatan/atau tidak berbuat lalai, yang melanggar perundang-undangan, tetapi juga apabila melanggar kesusilaan dan kepatutasn yang hidup dan harus diindahkan dalam masyarakat. Perbuatan melawan hukum yang diperluas ini tidaklah terjadi dengan mudah. Banyak peristiwa dan/atau kasus yang mendahuluinya (sebelum tahun 1919).

Kesadaran konsumen akan haknya yang masih rendah, ditunjang oleh tingkat pendidikan konsumen sendiri menjadi pemicu pentingnya perlindungan konsumen. Perlindungan konsumen diartikan cukup jelas, yang terwujud dalam perkataan, segala upaya yang menjamin adanya kepastian hukum untuk memberikan perlindungan kepada konsumen. Pengertian tersebut 
diparalelkan dengan definisi konsumen yaitu : setiap orang pemakai barang dan/atau jasa yang tersedia di masyarakat, baik bagi kepentingan diri sendiri, keluarga, orang lain maupun makhluk hidup lain dan tidak untuk diperdagangkan.

Mantan Presiden Amerika Serikat, John F. Kennedy, pernah mengemukakan 4 hak dasar konsumen, yaitu:

1. the rights to safe products;

2. the rights to be informed about products;

3. the rights to definite choices in selecting products;

4. the rights to be heard regarding consumer interests.

Resolusi PBB No. 39/248 Tahun 1985 tentang Perlindungan Konsumen (Guidelines for Consumer Protection) juga merumuskan berbagai kepentingan konsumen yang perlu dilindungi:

1. Perlindngan konsumen dari bahaya-bahaya terhadap kesehatan dan keamanannya.

2. Promosi dan perlindungan kepentingan ekonomi sosial konsumen.

3. Tersedianya informasi yang memadai bagi konsumen untuk memberkan kemampuan mereka melakukan pilihan yang tepat sesuai kehendak dan kebutuhan pribadi.

4. Pendidikan konsumen

5. Tersedia upaya ganti rugi yang efektif.

Kebebasan untuk membentuk organisasi konsumen atau organisasi lainnya yang relevan dan memberikan kesempatan kepada organisasi tersebut untuk menyuarakan pendapatnya dalam proses pengambilan keputusan yang menyangkut kepentingan mereka.

Lahimya UUPK tidak dimaksudkan untuk mematikan usaha para pelaku usaha, tetapi justru sebaliknya, sebab perlindungan konsmen dapat mendorong iklim berusaha yang sehat, serta lahirnya perusahaan yang tangguh dalam menghadapi persaingan melalui penyediaan barang dan/atau jasa yang berkualitas.

Masalah tanggung jawab hukum produsen atau pelaku usaha menurut UUPK memiliki dua prinsip penting yaitu tanggung jawab produk dan tanggung jawab profesional. Tanggung jawab produk (product liability) adalah tanggung jawab produsen untuk produk yang dibawanya ke dalam peredaran, yang menimbulkan atau menyebabkan kerugian karena cacat yang melekat pada produk tersebut, produk ini dapat diartikan sebagai barang, baik yang bergerak maupun tidak brrgerak. Tanggung jawab itu dapat bersifat kontraktual atau berdasarkan undang-undang. Sedangkan tanggung jawab profesional lebih berhubungan dengan jasa. Tanggung jawab profesional adalah tanggung jawab hukum dalam hubungan dengan jasa profesional yang diberikan kepada klien yang timbul karena pelaku usaha tidak memenuhi perjanjian yang mereka sepakati dengan klien mereka atau akibat kelalaian penyedia jasa yang mengakibatkan terjadinya perbuatan melawan hukum.

Pelaku usaha yang meliputi bentuk/ jenis usaha sebagaimana yang dimaksud dalam UUPK, sebaiknya ditentukan urutan-urutan yang seharusnya digugat oleh konsumen manakala dirugikan oleh pelaku usaha. Urutan-urutan tersebut sebaiknya disusun sebagai berikut:

1. yang pertama digugat adalah pelaku usaha yang membuat produk tersebut jika berdomilisi di dalam negeri dan domisilinya diketahui oleh konsumenyang dirugikan.

2. apabila produk yang merugikan konsuen tersebut diproduksi di luar negeri, maka yang digugat adalah importirnya, karena UUPK tidak mencakup pelaku usaha di luar negeri.

3. apabila produsen maupun importir dari suatu produk tidak diketahui, maka yang digugat adalah penjual dari siapa konsumen mebeli barang tersebut.

Urutan-urutan pihak yang digugat tersebut juga mempertimbangkan tentang kompetensi pengadilan maupun BPSK, karena siapapun yang digugat oleh konsumen, pengadilan atau BPSK yang kompeten adalah pengadilan atau BPSK yang berada di wilayah tempat tinggal konsumen, sehingga tidak memberatkan konsumen.

Upaya yang dapat dilakukan jika konsumen dirugikan dapat mengajukan pengaduan kepada:

1. Asosiasi industri yang merupakan lembaga yang juga dapat menjadi alternatif konsumen 
menyampaikan pengaduan adalah Assosiasi Industri. Terdapat 2 pendekatan pengajuan pengaduan, yaitu: fungsi penanganan pengaduan konsumen langsung ditangani pengurus assosiasi; atau assosiasi yang membentuk lembaga khusus yang berfungsi menangani sengketa konsumen, seperti assosiasi industri asuransi membentuk Badan Mediasi Asuransi Indonesia.

2. Menulis surat pembaca di media cetak dengan menulis pengalaman buruk di media cetak tentang suatu produk tingkat penyelesaian sangat rendah karena tergantung kepedulian dari pelaku usaha aka nama baiknya. Namun cara ini baik untuk pendidikan konsumen lain agar mengetahui info barang tersebut.

3. Membuat pengaduan ke Lembaga Perlindungan Konsumen Swadaya Masyarakat (LPKSM). Membuat pengaduan ke LPKSM dapat dengan berbagai akses, seperti: surat, telepon, datang langsung, e-mail, SMS. Agar ditindak lanjuti, pengaduan konsumen harus dilakukan tertulis atau datang langsung ke LPKSM dengan mengisi form pengaduan konsumen. Mekanisme LPKSM dalam menyelesaikan sengketa konsumen adalah dengan mengupayakan tercapainya kesepakatan antara konsumen dengan pelaku usaha melalui mediasi atau konsiliasi.

4. Membuat pengaduan/laporan tindak pidana ke - kepolisian. Dalam beberapa kasus pelanggaran terhadap hak konsumen ada yang berdimensi pidana, oleh karena itu dapat diadukan ke Kepolisian. Laporan / pengaduan ke kepolisian dapat menjadi dasar bagi kepolisian untuk mengambil langkah hukum/ polisional sehingga korban tidak berjatuhan lagi.

5. Mengirimkan somasi ke pelaku usaha. Somasi selain berisi teguran, juga memberi kesempatan terakhir kepada tergugat untuk berbuat sesuatu dan atau untuk menghentikan suatu perbuatan sebagaimana tuntutan pihak penggugat. Cara ini lebih efektif, terlebih ketika menyangkut kepentingan publik, akan sangat bagus somasi dilakukan kolektif dan terbuka.
6. Mengajukan gugatan secara perorangan. Mengajukan gugatan perorangan untuk masalah sengketa konsumen sangat tidak efektif, karena biaya akan sangat mahal dan lamanya waktu penyelesaian.

7. Mengajukan gugatan perdata secara perwakilan kelompok(Class Action). Gugatan Perwakilan kelompok merupakan cara yang praktis, dimana gugatan secara formal cukup diwakili beberapa korban sebagai wakil kelas. Namun apabila gugatan dikabulkan dan telah mempunyai kekuatan hukum tetap, korban lain yang secara formal tidak ikut menggugat dapat langsung menuntut ganti rugi berdasarkan putusan pengadilan tersebut. Selain dalam UUPK, gugatan class action juga diatur dalam UU Jasa Konstruksi. Gugatan ini baik dipakai untuk kasus-kasus pelanggaran hak konsumen secara massal.

8. Meminta Lembaga Perlindungan Konsumen Swadaya Masyarakat (LPKSM) mengajukan gugatan legal standing

Menurut Pasal 46 ayat (1) Huruf (c) UUPK menyebutkan bahwa LPKSM dapat mengajukan gugatan legal standing dengan memenuhi syarat, yaitu:

a. Berbentuk badan hukum atau yayasan;

b. dalam anggaran dasarnya menyebutkan dengan tegas bahwa tujuan didirikannya organisasi tersebut adalah untuk kepentingan perlindungan konsumen; dan

c. telah melaksanakan kegiatan sesuai dengan anggaran dasarnya.

9. Penyelesian sengketa konsumen Melalui Badan Penyelaian Sengketa Konsumen (BPSK). Lembaga ini pendiriannya menjadi tanggungjawab pemerintah, didirikan ditiap pemerintahan Kota/Daerah tingkat II. Tujuan BPSK untuk penyelesaian sengketa konsumen di luar pengadilan (Pasal 49 Ayat (1) UUPK) melalui cara mediasi atau arbitrase atau konsiliasi yang anggotanya terdiri dari unsur:
a. Pemerintah;
b. Lembaga konsumen; dan
c. Pelaku usaha (Pasal 49 Ayat (3) UUPK). 
Tugas dan wewenang BPSK, meliputi:

1.Penanganan dan penyelesaian sengketa konsumen melalui mediasi/arbitrase/konsiliasi;

2. konsultasi perlindungan konsumen;

3. pengawasan terhadap pencantuman klausula baku;

4. melaporkan kepada penyidik umum apabila terjadi pelanggaran ketentuan dalam UUPK;

5. menerima pengaduan baik tertulis maupun tidak tertulis dari konsumen;

6. meneliti dan memeriksa sengketa perlindungan konsumen;

7. memanggil pelaku usaha yang diduga telah melakukan pelanggaran;

8. memanggil dan menghadirkan saksi, saksi ahli dan atau setiap orang yang dianggap mengetahui pelanggaran terhadap UUPK;

9. meminta bantuan penyidik untuk menghadirkan pelaku usaha, saksi, saksi ahli atau setiap orang sebagaimana yang diatur dalam hukum acara di Indonesia.

BPSK merupakan badan yang dibentuk melalui Keppres No. 90 Tahun 2001 di sepuluh kota di Indonesia. BPSK merupakan suatu lembaga yang berwenang untuk menyelesaikan sengketa konsumen diluar pengadilan. Pasal 47 UUPK menyebutkan bahwa BPSK bertujuan menyelesaikan sengketa antara konsumen dan pelaku usaha, sehingga tercapai kesepakatan diantara mereka mengenai:

1. Bentuk dan besarnya ganti rugi, dan/atau;

2. Tindakan tertentu untuk menjamin tidak akan terjadi kembali atau tidak akan terulang kembali kerugian yang diderita oleh konsumen. Tindakan tertentu yang dimaksud adalah jaminan berupa pernyataan tertulis yang menerangkan bahwa tidak akan terulang kembali perbuatan yang telah merugikan kosnsumen tersebut.

Apabila konsumen merasakan dirugikan atas kerusakan, pencemaran dan/atau kerugian akibat mengkonsumsi barang dan/atau jasa yang dihasilkan atau diperdagangkan oleh pelaku usaha, maka berdasarkan ketentuan Pasal 19 UUPK, konsumen dapat menuntut ganti rugi. Atas tuntutan ganti rugi yang dilakukan oleh konsumen, pelaku usaha dapat memenuhinya dalam tenggang waktu 7 (tujuh) hari setelah tanggal transasksi. Sebaliknya apabila pelaku usaha menolak dan /atau tidak memberi tanggapan dan/atau tidak m,embayar gantio rugi seperti yang dituntut oleh konsumen, maka konsumen dapat mengajukan penyelesaian sengketanya terhadap pelaku usaha melalui BPSK

Tata cara penyelesaian sengketa konsumen melalui BPSK, menurut Pasal 16 Keputusan Menteri Perindustrian dan Perdagangan No. 350/MPP/Kep/12/2001, komnsumen yang dirugikan atau akhli warisnya atau kuasanya, mengajukan permohonan melalui Sekretariat BPSK yang berisi secara benar dan lengkap, tentang:

1. Nama dan alamat lengkap konsumen, akhli waris atau kuasanya disertai bukti diri.

2. Nama dan alamt lengkap pelaku usaha.

3. Barang dan /atau jasa yang diadukan.

4. Bukti perolehan (Bon, Faktur, Kuitansi dan dokumen bukti lain).

5. Keterangan tempat, waktu dan tdiperoleh barang dan/atau jasa.

6. Saksi yang mengetahui barang dan/atau jasa tersebut diperoleh.

7. Foto-foto barang dan kegiatan pelaksanaan jasa, bila ada.

Pasal 23 UU UUPK mengatur bahwa konsumen dapat mengajukan gugatan pada pelaku usaha melalui BPSK atau ke badan peradilan. Pasal 52 UUPK menerangkan bahwa salah satu kewenangan dari BPSK adalah menerima pengaduan baik tertulis maupun tidak tertulis dari konsumen tentang terjadinya pelanggaran terhadap perlindungan konsumen. Jadi, penyelesaian sengketa konsumen melalui BPSK tidak perlu persetujuan kedua belah pihak untuk memilih BPSK sebagai forum penyelesaian sengketa.

Berkaitan hal di atas, Pasal 45 UUPK memang menyebutkan bahwa penyelesaian sengketa konsumen dapat ditempuh melalui pengadilan atau di luar pengadilan berdasarkan pilihan sukarela para pihak yang bersengketa. Namun, ini tidak berarti dalammengajukan gugatan harus telah disetujui dahulu oleh para pihak. 
Menurut penjelasan Pasal 45 UUPK, ini artinya dalam penyelesaian sengketa konsumen tidak menutup kemungkinan penyelesaian damai oleh para pihak yang bersengketa. Pada setiap tahap diusahakan untuk menggunakan penyelesaian damai oleh kedua belah pihak yang bersengketa. Jadi, pengajuan gugatannya tidak harus atas persetujuan para pihak, tetapi para pihak dapat bersepakat untuk memilih perdamaian untuk penyelesaian sengketanya.

\section{Upaya BPSK Setelah Melakukan Pemanggilan Paksa Terhadap Pelaku Usaha Yang Menolak Hadir Pada Penyelesaian Sengketa Konsumen.}

Tujuan nasional sebagaimana ditegaskan dalam Pembukaan Undang -Undang Dasar 1945 yaitu melindungi segenap bangsa Indonesia dan seluruh tumpah darah Indonesia, memajukan kesejahteraan umum, mencerdaskan kehidupan bangsa, serta ikut serta melaksanakan ketertiban dunia yang berdasarkan kemerdekaan, perdamaian abadi, dan keadilan sosial. Tujuan nasional diwujudkan melalui pelaksanaan penyelenggaraan negara yang dilaksanakan melalui pembangunan nasional disegala aspek kehidupan. Pembangunan nasional adalah rangkaian upaya pembangunan yang berkesinambungan, yang meliputi seluruh kehidupan masyarakat, bangsa dan negara, untuk melaksanakan tugas mewujudkan tujuan nasional dalam Pembukaan UUD 1945. Pembangunan nasional meliputi juga pembangunan dibidang hukum yang salah satu prioritas adalah masalah pembangunan hukum nasional.

Pembangunan hukum sebagai alat pembaharuan masyarakat berkembang seiring dengan lajunya pembangunan disegala aspek kehidupan (law is a tool of social engineering). Terkait dengan fungsi hukum dalam konsep yang dikemukakan oleh Roscoe Pound tersebut diatas, lalu dimodifikasi menjadi hukum sebagai sarana pembaharuan masyarakat yang sejalan dengan definisi hukum menurut Mochtar Kusumaatmadja yang mendefiniskan hukum tidak hanya meliputi asas dan kaidah yang mengatur kehidupan manusia dalam masyarakat, melainkan juga termasuk lembaga dan proses dalam mewujudkan berlakunya hukum itu dalam kenyataan di masyarakat.

Mengingat bahwa hukum berperan sebagai sarana pembaharuan masyarakat, maka terhadap hukum tidak saja dibutuhkan perubahan yang menyangkut asas dan kaidah sebagai gejala normatif dalam hukum materil, namun dituntut pula perubahan pada lembaga dan proses yang terkait dengan hukum formil.

Hukum yang digunakan sebagai sarana pembaharuan itu dapat berupa undang - undang atau yurisprudensi atau kombinasi keduanya. Perkembangan yang terjadi dalam bidang perundang - undangan yang berfungsi sebagai sarana pembaharuan antara lain ditandainya dengan dibentuknya peraturan perundang undangan yang baru, antara lain UUPK, UndangUndang No. 30 Tahun 1999 Tentang Arbitrase dan Alternatif Penyelesaian Sengketa, dan peraturan perundang - undangan baru lainnya. Munculnya berbagai peraturan perundang undangan tersebut berdampak pula terhadap proses dan cara - cara penyelesaian sengketa yang terjadi dalam hubungan hukum tersebut.

Selaras dengan "lembaga dan proses", maka berhubungan erat dengan proses penyelesaian sengketa perdata yang dapat dilakukan melalui pengadilan(litigasi) maupun tidak melalui pengadilan (non litigasi). Apabila suatu sengketa perdata diselesaikan melalui pengadilan, maka penyelesaiannya melalui salah satu lingkungan peradilan menurut UUPK dan ketentuan yang digunakan adalah hukum acara perdata sebagai hukum perdata formil. Penyelesaian sengketa perdata yang dilakukan diluar pengadilan didasarkan pada UU No. 30 Tahun 1999 Tentang Arbitrase dan Alternatif Penyelesaian Sengketa yang menyediakan sarana negosiasi, mediasi, konsolidasi, dan arbitrase.

Saat ini, kaidah - kaidah hukum acara perdata sebagai hukum positif yaitu hukum yang berlaku sekarang bagi masyarakat tertentu dalam suatu daerah tertentu (Ius Constitutum), sebagian termuat dalam Het Herziene Indonesisch Reglement (H.I.R.) yang hanya berlaku khusus 
untuk daerah Jawa dan Madura, dan Rechtsreglement Buitengewesten (RB.g) yang berlaku untuk kepulauan lainnya di Indonesia. Di samping itu, hukum acara perdata positif juga terdapat dalam UU No. 20 Tahun 1947 Tentang Banding, UU No. 4 Tahun 2004 Tentang Kekuasaan Kehakiman, UU No. 5 Tahun 2004 Jo UU No. 14 tahun 1985 Tentang Mahkamah Agung, UU No. 8 Tahun 1985 Tentang Peradilan Umum, dan undang-undang lainnya.

Perkembangan hukum melalui "lembaga dan proses", berpengaruh pula terhadap perkembangan hukum dibidang acara perdata. Retnowulan Sutantio mendefinisikan hukum acara perdata sebagai hukum formil yaitu keseluruhan kaidah hukum yang menentukan dan mengatur cara bagaimana melaksanakan hak hak dan kewajiban perdata sebagaimana yang diatur dalam hukum perdata materil, sedangkan Sudikno Mertokusumo mengatakan bahwa hukum acara perdata mengatur tentang bagaimana caranya mengajukan tuntutan hak, memeriksa serta memutuskan serta pelaksanaan dari putusannya. Tuntutan hak dalam hal ini tidak lain adalah tindakan yang bertujuan memperoleh perlindungan hukum yang diberikan oleh pengadilan untuk mencegah "eigenrichting" atau tindakan main hakim sendiri.

Penyelesaian sengketa perdata yang dilakukan diluar pengadilan didasarkan pada Undang-Undang No. 30 Tahun 1999 Tentang Arbitrase dan Alternatif Penyelesaian Sengketa yang menyediakan sarana negosiasi, mediasi, konsolidasi, dan arbitrase.

Pada saat ini sasaran setiap negara, setiap perusahan (produsen) adalah menuju era pemasaran global pada dasarnya dapat merubah berbagai konsep, cara pandang dan cara pendekatan mengenai banyak hal termasuk strategi pemasaran. Perubahan pemasaran tersebut membawa pengaruh pula tentang konsep perlindungan konsumen secara global.

UUPK sebagai salah satu upaya Program Pembentukan Peraturan Perundang-undangan dengan tujuan sebagai upaya mewujudkan supremasi hukum, untuk mengimbangi dari keberadaan dari pelaku usaha. Pelaku usaha adalah pelaku usaha dan konsumen adalah konsumen dengan UUPK diharapkan tercipta keadaan yang seimbang, serasi dan selaras antar keduanya.

UUPK dimaksudkan menjadi landasan hukum yang kuat bagi pemerintah dan lembaga konsumen swadaya masyarakat untuk melakukan upaya pemberdayaan konsumen melalui pembinaan dan pendidikan konsumen. Upaya pemberdayaan ini penting karena tidak mudah mengharapkan kesadaran pelaku usaha yang pada dasarnya prinsip ekonomi pelaku usaha adalah mendapat keuntungan yang semaksimal mungkin dengan modal seminimal mungkin. Prinsip ini sangat potensial merugikan kepentingan konsumen, baik secara langsung maupun tidak langsung.

Dalam melakukan setiap kegiatan usaha, para pelaku usaha harus memperhatikan setiap ketentuan dalam UUPK, ataupun dengan ketentuan lain yang terkait. UUPK berkaitan dengan perbuatan melawan hukum yang dilakukan oleh pelaku usaha. Dalam ilmu hukum dikenal 3 kategori dari perbuatan melawan hukum, yaitu sebagai berikut:

1. Perbuatan melawan karena kesengajaan.

2. Perbuatan melawan tanpa kesalahan (tanpa unsur kesengajaan maupun kelalaian).

3. Perbuatan melawan hukum karena kesalahan.

Tanggung jawab hukum atas perbuatan yang menimbulkan kerugian kepada pihak lain diatur dalam Pasal 1365 dan 1366 KUHPerdata yang menyatakan sebagai berikut:

\section{Pasal 1365 KUHPerdata:}

"Tiap perbuatan melanggar hukum yang menimbulkan kerugian kepada orang lain, mewajibkan orang yang karena kesalahannya menimbulkan kerugian itu, mengganti kerugian tersebut".

\section{Pasal 1366 KUHPerdata:}

"Setiap orang bertanggung jawab, tidak saja untuk kerugian yang disebabkan oleh perbuatannya, tetapi juga untuk kerugian yang disebabkan oleh kelalaian dan kurang hatihatinya" 
Makna dari tanggung jawab sama dengan tanggung gugat. Bila ditinjau dari pihak yang menimbulkan kerugian kepada orang lain disebut tanggungjawab, yaitu pihak yang menimbulkan kerugian kepada orang lain bertanggungjawab untuk mengganti kerugian pihak lain itu. Dan bila ditinjau dari pihak yang menderita kerugian oleh perbuatan orang lain disebut tanggung gugat, yaitu pihak yang yang dirugikan mempunyai hak gugat atau berhak menggugat pihak yang menimbulkan kerugian padanya untuk memperoleh ganti rugi-

Unsur-unsur pokok dari perbuatan melawan hukum bedasarkan Pasal 1365 KUHPerdata adalah sebagai berikut:

1. Adanya suatu perbuatan

2. Perbuatan melawan hukum

3. Adanya kesalahan dari pihak pelaku (baik kesengajaan ataupun kelalaian)

4. Adanya kerugian bagi korban

5. Adanya hubungan kausal antara perbuatan dengan kerugian

Tanggung gugat produk atau product liability adalah suatu konsepsi hukum yang intinya dimaksudkan memberikan perlindungan kepada konsumen dari beban untuk membuktikan bahwa kerugian konsumen timbul akibat kesalahan dalam proses produksi dan sekaligus melahirkan tanggung jawab produsen untuk memberikan ganti rugi.

Mengenai tanggung jawab pelaku usaha, UUPK mengatur dalam Pasal 19 angka 1 yang menyatakan:

"Pelaku usaha bertanggung jawab memberikan ganti rugi atas kerusakan, pencemaran, dan/atau kerugian konsumen akibat mengkonsumsi barang dan/atau jasa yang dihasilkan atau diperdagangkan."

Dalam rangka melindungi kepentingan konsumen dari perbuatan melawan hukum yang dilakukan oleh pelaku usaha, UUPK mengatur perbuatan-perbuatan yang dilarang bagi pelaku usaha dalam Bab IV. Menurut UUPK, penyelesaian dari permasalahan konsumen dapat dipecahkan melalui jalan peradilan maupun nonperadilan. Mereka yang bermasalah harus memilih jalan untuk memecahkan permasalahan mereka. Penyelesaian dengan cara non-peradilan bisa dilakukan melalui Alternatif Resolusi Masalah (selanjutnya disebut ARM) di BPSK, Lembaga Perlindungan Konsumen Swadaya Masyarakat (selanjutnya disebut LPKSM), Direktorat Perlindungan Konsumen atau lokasi-lokasi lain baik untuk kedua belah pihak yang telah disetujui.

Ketika kedua pihak telah memutuskan untuk melakukan penyelesaian non-peradilan, nantinya ketika mereka akan pergi ke pengadilan (lembaga peradilan) untuk masalah yang sama, mereka hanya dapat mengakhiri tuntutan mereka di pengadilan jika penyelesaian non peradilan gagal. BPSK adalah institusi non struktural yang memiliki fungsi sebagai "institusi yang menyelesaikan permasalahan konsumen diluar pengadilan secara murah, cepat dan sederhana". Badan ini sangat penting dibutuhkan di daerah dan kota di seluruh Indonesia. Anggota-anggotanya terdiri dari perwakilan aparatur pemerintah, konsumen dan pelaku usaha.

Konsumen yang bermasalah terhadap produk yang dikonsumsi akan dapat memperoleh haknya secara lebih mudah dan efisien melalui peranan BPSK. Selain itu bisa juga menjadi sebuah akses untuk mendapatkan infomasi dan jaminan perlindungan hukum yang sejajar baik untuk konsumen maupun pelaku usaha. Dalam menangani dan mengatur permasalahan konsumen, BPSK memiliki kewenangan untuk melakukan pemeriksaan atas kebenaran laporan dan keterangan dari para pihak yang bersengketa. Tagihan, hasil test lab dan bukti-bukti lain oleh konsumen dan pengusaha dengan mengikat penyelesaian akhir. BPSK mempunyai tugas-tugas utama begai berikut:

1. Menangani permasalahan konsumen melalui mediasi, konsiliasi atau arbitrasi;

2. Konsultasi konsumen dalam hal perlindungan konsumen;

3. Mengontrol penambahan dari bagian-bagian standarisasi;

4. Memberikan sanksi administrasi terhadap pengusaha yang menyalahi aturan;

Tata cara penyelesaian sengketa melalui BPSK adalah:

1. Konsiliasi: 
a.BPSK membentuk sebuah badan sebagai pasif fasilitator;

b.Badan yang membiarkan yang bermasalah untuk menyelesaikan masalah mereka secara menyeluruh oleh mereka sendiri untuk bentuk dan jumlah kompensasi;

c. Ketika sebuah penyelesaian dicapai, itu akan dinyatakan sebagai persetujuan rekonsiliasi yang diperkuat oleh keputusan BPSK;

d. Penyelesaian dilaksanakan paling lama 21 hari kerja.

2. Mediasi:

a. BPSK membentuk sebuah fungsi badan sebagai fasilitator yang aktif untuk memberikan petunjuk, nasehat dan saran kepada yang bermasalah;

b. Badan ini membiarkan yang bermasalah menyelesaikan permasalahan mereka secara menyeluruh untuk bentuk dan jumlah kompensasinya;

c. Ketika sebuah penyelesaian dicapai, itu akan diletakkan pada persetujuan rekonsiliasi yang diperkuat oleh keputusan BPSK;

d. Penyelesaian dilaksanakan paling lama 21 hari kerja.

3. Arbitrasi:

Pihak yang bermasalah memilih arbitrasi dalam menyelesaikan masalah konsumen, Kedua belah pihak seutuhnya membiarkan badan tersebut menyelesaikan permasalahan mereka, BPSK membuat sebuah penyelesaian final yang mengikat, Penyelesaian harus diselesaikan dalam jangka waktu 21 hari kerja paling lama. Ketika kedua belah pihak tidak puas pada penyelesaian tersebut, kedua belah pihak dapat mengajukan keluhan kepada pengadilan negeri dalam 14 hari setelah penyelesaian di informasikan.

Penyelesaian sengketa konsumen oleh BPSK dilakukan dalam bentuk kesepakatan yang dibuat dalam perjanjian tertulis yang ditandatangani oleh para pihak yang bersengketa, yang dikuatkan dalam bentuk keputusan BPSK (SK No. 350/ MPP/Kep/12/2000 tentang Badan Penyelesaian Sengketa Konsumen). Putusan yang dikeluarkan BPSK dapat berupa perdamaian, gugatan ditolak, atau gugatan dikabulkan. Dalam hal gugatan dikabulkan, maka dalam amar putusan ditetapkan kewajiban yang harus dilakukan oleh pelaku usaha, berupa pemenuhan ganti rugi dan atau sanksi administratif berupa penetapan ganti rugi paling banyak Rp 200.000.000,00.

Pasal 23 UU UUPK mengatur bahwa konsumen dapat mengajukan gugatan pada pelaku usaha melalui badan penyelesaian sengketa konsumen atau ke badan peradilan. Kemudian, menurut Pasal 52 UUPK, salah satu kewenangan dari BPSK adalah menerima pengaduan baik tertulis maupun tidak tertulis dari konsumen tentang terjadinya pelanggaran terhadap perlindungan konsumen. Jadi, penyelesaian sengketa konsumen melalui BPSK tidak perlu persetujuan kedua belah pihak untuk memilih BPSK sebagai forum penyelesaian sengketa.

Berkaitan hal di atas, pasal 45 UUPK memang menyebutkan bahwa penyelesaian sengketa konsumen dapat ditempuh melalui pengadilan atau di luar pengadilan berdasarkan pilihan sukarela para pihak yang bersengketa. Namun, ini tidak berarti dalam mengajukan gugatan harus telah disetujui dahulu oleh para pihak. Menurut penjelasan Pasal 45 UUPK, ini artinya dalam penyelesaian sengketa konsumen tidak menutup kemungkinan penyelesaian damai oleh para pihak yang bersengketa. Pada setiap tahap diusahakan untuk menggunakan penyelesaian damai oleh kedua belah pihak yang bersengketa. Jadi, pengajuan gugatannya tidak harus atas persetujuan para pihak, tetapi para pihak dapat bersepakat untuk memilih perdamaian untuk penyelesaian sengketanya.

Lain halnya dengan penyelesaian sengketa BPSK yang melalui cara konsiliasi atau mediasi atau arbitrase. Menurut Pasal 52 huruf(a) UUPK, BPSK berwenang untuk melaksanakan penanganan dan penyelesaian sengketa konsumen melalui mediasi atau arbitrase atau konsiliasi. Mengenai mediasi, arbitrase dan konsiliasi ini kemudian diatur lebih lanjut dalam Kepemenperindag No. 350/2001. Menurut pasal 4 ayat (1) Kepemenperindag No. 350/2001, penyelesaian sengketa konsumen oleh BPSK melalui cara konsiliasi atau mediasi atau arbitrase dilakukan atas dasar pilihan dan persetujuan para pihak yang bersangkutan. Jadi, yang perlu 
persetujuan para pihak adalah apabila penyelesaian sengketa konsumen di BPSK dilakukan dengan cara mediasi/konsiliasi/arbitrase. Seperti telah diuraikan di atas, konsumen dapat menggugat pelaku usaha ke BPSK atau ke badan peradilan. Namun, dalam hal sengketa itu bukan kewenangan BPSK, Ketua BPSK dapat menolak permohonan penyelesaian sengketa konsumen (Pasal 17 Kepemenperindag No. 350/2001).

Dalam hal telah ada perjanjian antara pelaku usaha dan konsumen mengenai forum penyelesaian sengketa, maka sudah seharusnya para pihak tunduk pada klausula tersebut. Ini mengacu pada pasal 1338 Kitab Undang-Undang Hukum Perdata(KUHPer), bahwa perjanjian yang dibuat secara sah mengikat para pihaknya sebagai undang-undang. Oleh karena itu, seharusnya penyelesaian sengketa dilakukan berdasar kesepakatan awal.

Pasal 52 huruf g UUPK memang memberikan kewenangan pada BPSK untuk memanggil pelaku usaha yang diduga telah melakukan pelanggaran terhadap perlindungan konsumen. Akan tetapi, BPSK tidak diberikan kewenangan untuk melakukan pemanggilan paksa terhadap pelaku usaha tersebut. Meski demikian, BPSK bisa meminta bantuan penyidik untuk menghadirkan pelaku usaha yang tidak bersedia memenuhi panggilan badan penyelesaian sengketa konsumen (Pasal 52 huruf i UUPK). Jadi, BPSK tidak memiliki kewenangan untuk melakukan pemanggilan paksa, tetapi BPSK bisa meminta bantuan pada penyidik untuk menghadirkan pelaku usaha. Penyidik di sini mengacu pada Pejabat Polisi Negara Republik Indonesia dan Pejabat Pegawai Negeri Sipil tertentu di lingkungan instansi pemerintah yang lingkup tugas dan tanggung jawabnya di bidang perlindungan konsumen (Pasal 59 ayat (1) UUPK).

Dalam hal pelaku usaha tetap tidak memenuhi panggilan BPSK, maka BPSK dapat mengadili sengketa konsumen tanpa kehadiran pelaku usaha. Hal ini mengacu pada Pasal 36 Kepemenperindag No. 350/2001, yaitu dalam hal pelaku usaha tidak hadir pada hari persidangan I (pertama),majelis hakim BPSK akan memberikan kesempatan terakhir kepada pelaku usaha untuk hadir pada persidangan II (kedua) dengan membawa alat bukti yang diperlukan. Jika pada persidangan II (kedua) pelaku usaha tidak hadir, maka gugatan konsumen dikabulkan oleh Majelis tanpa kehadiran pelaku usaha. Jadi, dalam hal pelaku usaha tidak menghadiri persidangan, maka BPSK dapat mengabulkan gugatan konsumen. Adapun putusan BPSK sendiri adalah putusan yang final dan telah mempunyai kekuatan hukum yang tetap (Pasal 54 UUPK jo Pasal 42 ayat (1) Kepemenperindag No. 350/2001).

Final artinya dalam badan penyelesaian sengketa konsumen tidak ada upaya banding dan kasasi (Penjelasan Pasal 54 ayat (3) UUPK). Putusan BPSK kemudian dapat dimintakan penetapan eksekusi oleh BPSK kepada Pengadilan Negeri di tempat konsumen yang dirugikan (Pasal 42 ayat (2) KepmenPerindag No. 350/2001).

Ketika pelaku usaha tidak mau memenuhi panggilan dari BPSK dalam hal menyelesaikan sengketa konsumen, pelaku usaha yang bersangkutan dapat dipanggil secara paksa. Pemanggilan pelaku usaha secara paksa seharusnya dapat dilakukan oleh BPSK meskipun tidak adanya Surat Keputusan Bersama antara Menteri Perdagangan dengan Kapolri. UUPK dapat memaksa pelaku usaha untuk memenuhi panggilan BPSK. Surat Keputusan Bersama ditanda-tangani antara Kapolri dan Menteri Perdagangan. Surat Keputusan Bersama hanya memperkuat upaya BPSK untuk memanggil pelaku usaha secara paksa karena biasanya dalam Surat Keputusan Bersama sudah ada klausul yang menjelaskan proses mediasi dan pemanggilan paksa oleh BPSK.

Saat ini, Kemendag juga telah memiliki penyidik, selain dari instansi lain termasuk kepolisian dan kementerian terkait. Karena itu, apabila diperlukan atau dimintakan oleh Kemendag dan BPSK, Polisi dapat melakukan upaya pemanggilan paksa terhadap terhadap pelaku usaha. Majelis BPSK juga dapat melakukan ketentuan pemanggilan paksa pada pelaku usaha sebgaimana yang diatur pada Pasal 52 UUPK. Pada praktik dilapangan, Kemendag mengakui bahwa aparat kepolisian pernah ragu dengan ketentuan ranah pidana/perdata untuk pemanggilan 
paksa pelaku usaha. Tetapi setelah penandatanganan Surat Keputusan Bersama, pelaku usaha harus turut dengan pemanggilan majelis BPSK untuk proses mediasi. Sebelum Surat Keputusan Bersama, hampir semua pelaku usaha melihat konteks legalistik UUPK. Pelaku usaha sering berdalih bahwa tidak ada ketentuan pemanggilan paksa oleh BPSK. Hal tersebut mengakibatkan banyak pelaku usaha yang tidak memenuhi panggilan majelis BPSK.

Pasal 52 UUPK dapat dikatakan sudah cukup akomodatif untuk menindak-lanjuti pengaduan konsumen yang merasa dirugikan oleh pelaku usaha. Prosedur pemanggilan pelaku usaha harus dilakuakn 3 kali. Apabila pada pemanggilan pertama dan kedua, pelaku usaha tidak hadir, majelis BPSK masih dapat melakukan pemanggilan 1 kali lagi. Pada pemanggilan ketiga, pelaku usaha harus hadir pada sidang majelis. Selain dapat melakukan sendiri, BPSK dapat meminta bantuan untuk memanggil secara paksa pelaku usaha dengan bantuan penyidik pegawai negeri sipil perlindungan konsumen atau PNS PK. BPSK dapat melihat ketentuan proses beracara pada petunjuk pelaksana dan petunjuk teknis dari UUPK. Apabila setelah tiga kali pemanggilan pelaku usaha tetap tidak hadir, majelis BPSK dapat mengabulkan gugatan konsumen dengan putusan verstek. Putusan verstek sudah lazim dilakukan sebagaimana diatur dalam ketentuan hukum acara perdata dan UUPK. Putusan verstek terhadap pelaku usaha sudah dilakukan oleh BPSK, seperti halnya pada pelaku usaha yang bergerak pada bidang perusahaan pengembang yang berada di wilayah Jakarta Barat.

\section{Penutup \\ 1.Simpulan}

Berdasarkan pemaparan di atas, maka dapat ditarik 2 simpulan mengenai permasalahan hukum, yaitu:

1.Implementasi penegakan hukum perlindungan konsumen dalam praktik belum sepenuhnya dapat dilakukan. Hal tersebut dapat terlihat selain dari kesadaran kemampuan dan kemandirian konsumen untuk melindungi diri terhadap hak dan kewajibanya, juga dapat terlihat dari aparat penegak hukum yang belum melaksanakan kinerja secara maksimal.

2. upaya yang dapat dilakukan BPSK setelah melakukan pemanggilan paksa terhadap pelaku usaha yang menolak hadir pada penyelesaian sengketa konsumen dapat melakukan putusan verstek apabila pelaku usaha tidak hadir sebanyak 3 kali pada pemanggilan sidang oleh BPSK sebagaimana yang diatur dalam Pasal 52 UUPK dan Kemendag No. 35/2001.

\section{B. Saran}

1. Kesadaran hukum konsumen terhadap hak dan kewajibannya perlu ditingkatkan guna membantu terciptanya sistem hukum yang baik (khususnya hukum tentang perlindungan konsumen)

2. Masih terdapat kerancuan terhadap kewenangan BPSK pada pemanggilan paksa pada pelaku usaha. banyak pelaku usaha yang belum mengetahui kewenangan BPSK tersebut, sehingga diharapkan ketentuan megenai hal tersebut dapat dikaji ulang kembali.

\section{DAFTAR PUSTAKA}

Ahmadi Miru, Prinsip-Prinsip Perlindungan Hukum bagi Konsumen di Indonesia, Disertasi Program Pascasarjana Universitas Airlangga, Surabaya, 2000

A.Z Nasution, Hukum Perlindungan Konsumen Suatu Pengantar, Daya Widya, Jakarta, 1999.

C.S.T. Kansil, Pengantar Ilmu Hukum Dan Tata Hukum Indonesia, Penerbit Balai Pustaka, Jakarta, 1989.

Lili Rasjidi dan Ira Rasjidi, Dasar - Dasar Filsafat dan Teori Hukum, Citra Aditya Bakti, Bandung, 2001.

Man S Sastrawidjaja, Asuransi Pertanggungjawaban Pelaku Usaha Dalam Hubungan Dengan UU No. 8 Tahun 1999 Tentang Perlindungan Konsumen, Mimbar Hukum Majalah Fakultas Hukum UGM.

Munir Fuady, Perbuatan Melawan Hukum, PT Citra Aditya Bakti, Bandung, 2005. 
Mochtar Kusumaatmadja, Konsep Konsep Hukum Dalam Pembangunan, Penerbit Alumni, Bandung, 2002.

Nahattands V Lamboek, Product Liability Dalam Rangka Perlindungan Konsumen", Lokakarya Rancangan UUPK, Kerjasama Lembaga Penelitian UI dengan Departemen Perindustrian dan Perdagangan tanggal 16 Oktober 1996, Jakarta.

Retnowulan Sutantio dan Iskandar Oeripkartawinata, Hukum Acara Perdata dalam Teori dan Praktek, Mandar Maju, Bandung, 1993

Ronny Hanitijo Soemitro, Metodologi Penelitian Hukum dan Jurimetri, Ghalia Indonesia, Jakarta, 1988

Shidarta, Hukum Perlindungan Konsumen, PT Gramedia Widiasarna Indonesia, Jakarta, 2004.

Sri redjeki Hartono, Hukum Perlindungan Konsumen Di Indonesia (Tinjauan Makro),Mimbar Hukum Majalah Fakultas Hukum UGM, No. 39/X/2001

Sudikno Mertokusumo, Hukum Acara Perdata Indonesia, Penerbit Liberty, Yogyakarta, 1998

Peraturan Perundang-undangan

Undang-Undang No. 8 Tahun 1999 Tentang Perlindungan Konsumen

Kitab Undang-Undang Hukum Perdata

Kitab Undang-Undang Hukum Acara Perdata atau Herzeine Inlandsch Reglement (HIR)

Undang-Undang No. 30 Tahun 1999 Tentang Arbitrase dan Alternatif Penyelesaian Sengketa

Peraturan Mahkamah Agung RI No. 01 Tahun 2006 Tentang Tata Cara Pengajuan Keberatan Terhadap Putusan Badan Penyelesaian Sengketa Konsumen.

Keputusan Menteri Perindustrian dan Perdagangan Republik IndonesiaNomor 350/Mpp/Kep/12/2001 Tahun 2001 Tentang Pelaksanaan Tugas dan Wewenang Badan Penyelesaian Sengketa Konsumen

\section{Sumber Lain}

shaphira.multiply.com/journal

www.kditjenpdn.depdag.go.id

www.pemantauperadilan.com

http://panduankonsumen.com/panduan-tentangprinsip-kerja-badan-penyelesaiansengketa-konsumen-bpsk

http://www.medanbisnisdaily.com/news/read/ 2013/12/18/68583/pelaku-usaha seringmenolak-panggilan-bpsk 